\title{
El papel de la música en la configuración de la esfera pública española durante el siglo XIX. Ideas y pautas de investigación*
}

\author{
The Role of Music in Shaping the Spanish Public \\ Sphere during the Nineteenth Century. \\ Ideas and Guidelines for Research
}

Como en el resto del mundo occidental, en España se fue configurando una nueva esfera pública desde mediados del siglo XVIII. En años recientes la historiografia española ha avanzado de manera notable en el estudio de la historia de esa configuración, desde sus inicios en las academias y las sociedades de amigos dieciochescas, hasta las formas más complejas de lo público en la sociedad actual. No obstante, esta historia adolece de enormes lagunas y áreas incógnitas. Una de esas lagunas es la referida al papel que jugó la música en el proceso de creación de nuevos espacios públicos de sociabilidad, debate y actividad cívica en la época liberal. Este artículo introduce algunas ideas y propone pautas de investigación sobre cómo abordar el estudio de la conformación de un moderno público musical en la España del siglo XIX.

Palabras clave: esfera pública, música en la España isabelina, comunidad de oyentes, público, espacios de sociabilidad, sociedades artísticas, jardines de recreo, bandas de música, agrupaciones corales.

As in the rest of the Western world, a new public sphere was being shaped in Spain since the mid-eighteenth century. In recent years, Spanish historiography has made remarkable progress in studying the history of this process, from its early stages in the academies and societies of friends, to the more complex forms of the public in today's society. Nevertheless, there are enormous gaps and unknown areas in this history. One of these understudied aspects refers to the role music played in the process of creating new public spaces of sociability, debate and civic activity during the liberal era. This article introduces some ideas and suggests guidelines for research on how to approach the study of the shaping of a modern musical public in nineteenth-century Spain.

Keywords: public sphere, music in Isabelline Spain, community of listeners, public, spaces for sociability, artistic societies, recreational gardens, music bands, choral groups.

Desde que Jürgen Habermas formulara en 1962 su modelo teórico de interpretación en Strukturwandel der Öffentlichkeit, el concepto de "esfera pública" se ha convertido en un instrumento de análisis utilizado por una amplia variedad de investigadores en diversos campos de estudio. El marco

*Una versión preliminar de este artículo se presentó en el marco de las II Jornadas de estudio sobre la vida musical en la España isabelina "Definiciones y fronteras", organizadas por la Sociedad para el Estudio de la Música Isabelina en Madrid, los días 7 y 8 de marzo de 2014. 
de interpretación habermasiano tardó más de tres décadas en hacerse útil por no haber sido traducido al inglés hasta 1989 , pero a partir de esta fecha su uso ha proliferado tanto en el ámbito del debate teórico como en su aplicación para la historia de las sociedades modernas ${ }^{1}$. Como en el resto del mundo occidental, en España se fue configurando una nueva esfera pública desde mediados del siglo XVIII. En años recientes la historiografia española ha avanzado de manera notable en el estudio de la historia de esa configuración, desde sus albores en los mentideros, las academias y las sociedades de amigos dieciochescas, hasta las formas más complejas de lo público en la sociedad actual ${ }^{2}$. No obstante, esa historia adolece de enormes lagunas y áreas incógnitas. Una de esas lagunas es la referida al papel que jugó la música en el proceso de creación de nuevos espacios públicos de sociabilidad, debate y actividad cívica en la época liberal.

En las páginas que siguen se propone una reflexión sobre la utilidad del uso del modelo propuesto por Habermas para estudiar la música isabelina en su contexto histórico. Es decir, relacionando las composiciones, las interpretaciones, las actuaciones y los comentarios musicales durante aquel periodo con su entorno social, político y cultural y cómo la música contribuyó a configurar la esfera pública española. No es mi intención ofrecer una síntesis concluyente sobre un tema tan extenso y complejo. Por el contrario, el objetivo de este artículo es aportar algunas ideas y proponer pautas de investigación sobre cómo abordar el estudio de la conformación de un moderno público musical en la España del siglo XIX.

La utilización del modelo de Habermas para el estudio propuesto tiene una ventaja y busca ofrecer una aportación. La ventaja es que permite

\footnotetext{
${ }^{1}$ Jürgen Habermas: Strukturwandel der Öffentlichkeit; Untersuchungen zu einer Kategorie der bürgerlichen Gesellscahft, Neuwied, H. Luchterhand, 1962. Traducido al francés en 1978, fue traducido después al español, Historia y crítica de la opinión pública: la transformación estructural de la vida pública, Barcelona, 1981; y al inglés The Structural Transformation of the Public Sphere, Cambridge, Massachussetts, 1989, siendo esta la edición de mayor difusión e impacto.

2 Una buena porción de la reciente producción historiográfica sobre este tema procede del trabajo realizado por varios grupos de investigación en universidades españolas entre las que cabe destacar la Complutense de Madrid, la Universidad de Cádiz y la Universidad del País Vasco. Véase María Victoria López-Cordón Cortezo: "El nacimiento de la esfera pública: camarillas, familias y criaturas del rey en la corte borbónica", Población y grupos sociales en el Antiguo Régimen, Juan Jesús Bravo Caro y Luis Sanz Sampelayo (coords.), Universidad de Málaga, 2009; Javier Usoz Otal: "La 'nueva política' ilustrada y la esfera pública: las introducciones a la economía en el siglo XVIII español", Revista de Estudios Políticos, 153, Madrid, 2011, pp. 11-46; Elena Martínez Alcázar: "Rasgando el velo: la mujer española en la esfera pública en el siglo XVIII", Apariencias de persuasión: construyendo significados en el arte, María Concepción de la Peña Velasco y María Albaladejo Martínez (coords.), Universidad de Murcia, 2012, pp. 303-331; Mónica Burguera López: "Mujeres y revolución liberal en perspectiva. Esfera pública y ciudadanía femenina en la primera mitad del siglo XIX en España", Cuando todo era posible: liberalismo y antiliberalismo en España e Hispanoamérica (1740-1842), Encarnación García Monerris (ed.), Madrid, Silex, 2016, pp. 257-296; Marieta Cantos Casenave (coord.): Redes y espacios de opinión pública: de la Ilustración al Romanticismo. Cádiz, América y Europa ante la Modernidad: 1750-1850, Universidad de Cádiz, 2004.
} 
estudiar el papel de la música utilizando una perspectiva integrada al relacionarla con el contexto social, político y cultural en que se produjo. La mayor parte de los estudios sobre la música de la época de Isabel II suelen examinar espacios compartimentados de audición, composición y divulgación. La mayoría se interesan por el papel de la música en la conformación de la cultura dominante del periodo, es decir, de lo que hemos venido en llamar cultura burguesa o de la sociedad de buen tono. Prestan atención a la música de los salones, de los teatros, de los cafés y, pasando el tiempo, de las primeras salas de conciertos. Otros escudriñan el pausado declive de la música de patronazgo eclesiástico. Finalmente, algunos exploran recintos de producción y audiencia musical que sobrepasaron el ámbito de los espacios privados o públicos de la burguesía o de la iglesia, cual fuera el caso de las bandas de música que comenzaron a proliferar desde el trienio liberal. La esfera pública ofrece un marco analítico en el que se pueden casar todas esas piezas para ofrecer una visión integrada.

La aportación, aunque modesta, se dirige al largo y sostenido debate intelectual sobre los usos del marco teórico habermasiano, en el que se plantean cuestiones sobre el cómo y cuándo se conforma una esfera pública burguesa, dónde situar los límites entre la esfera privada y la pública o qué es exactamente una esfera pública ${ }^{3}$. Uno de los problemas debatidos es el abuso en el uso del concepto esfera pública entre investigadores, tanto en el área de las ciencias sociales como en el de las humanidades, hasta el punto de haberlo convertirlo en un cliché aplicable a circunstancias muy dispares. La causa de esta dispersión se debe a que Habermas entendió la esfera pública como la variedad de espacios que fueron surgiendo a lo largo del siglo XVIII donde individuos privados se constituyeron en públicos para opinar, cuestionar y crear nuevas ideas y valores ${ }^{4}$. Habermas analizó algunos de esos espacios tales como las coffeehouses, los salones o los clubs, todos localizados en sociedades del norte y centro de Europa. Su marco interpretativo ha demostrado ser bastante acertado para estudiar las sociedades de la Edad Moderna, pero quedó muy abierto y ha resultado ser más problemático cuando se aplica a otras áreas geográficas y a las más complejas sociedades del mundo contemporáneo. Para evitar el riesgo de vulgarización y entender las vías en que los individuos privados aprendieron a comunicarse de forma pública durante la era de la Ilustración y del liberalismo, o la manera en la que crearon instituciones independientes del

\footnotetext{
${ }^{3}$ La bibliografía sobre este tema es extensísima, una buena síntesis sobre los estados de la cuestión se puede encontrar en Simon Susen: "Critical Notes on Habermas's Theory of the Public Sphere", Sociological Analysis, 5, 1, 2011, pp. 37-62; Nick Crossley y John Michael Roberts (eds.): After Habermas: New Perspectives on the Public Sphere, Oxford, Blackwell, 2004.

${ }^{4} \mathrm{~J}$. Habermas: Historia y crítica de la opinión pública: la transformación estructural de la vida pública, Barcelona, Gustavo Gili, 1982, p. 53 y ss.
} 
Estado para promover el debate o la creatividad racional, debemos descender a los niveles más elementales de organización y a las formas más específicas de trabajo que los hicieron posible. El ejemplo lo marcan trabajos como los de Adrian Johns, David Zarett o Gillian Russell, que estudian las fuerzas creativas, comerciales y políticas que configuraron la primera esfera pública de la letra impresa, de la representación escénica y de los espacios de opinión en Inglaterra, escudriñando desde las tiendas de los libreros y las fábricas de papel a los teatros y los círculos de lectura y opinión que transformaron el mundo del secreto político característico del siglo XVII en una cultura de diálogo abierto. Todo situado en el contexto de la revolución científica y cultural que se inició en el país a partir de $1688^{5}$. En el campo de la musicología el reciente volumen editado por Christian Speck sobre el papel de los cuartetos de cuerda en la creación de una esfera pública en diversos lugares de Europa es un buen ejemplo de contribución a estos debates; pero lo cierto es que en este terreno es mucho lo que queda por hacer ${ }^{6}$.

Los trabajos mencionados, ejemplo de un amplio repertorio de investigación sobre la aplicación del modelo habermasiano, demuestran de manera inequívoca dos cosas. La primera es que la esfera pública no constituye una realidad indivisa, sino que hay que entenderla como un conjunto de comunidades de individuos que forman espacios públicos diversos. La segunda es que los conceptos de público y privado difieren dependiendo de cada cultura nacional. Cada país fue articulando sus esferas públicas conforme a procesos en los que hallamos una combinación de similitudes y particularidades. En Inglaterra, por ejemplo, se detecta una incipiente temprana esfera pública en la nave central de la catedral de San Pablo así como en la Bolsa, lugares públicos donde se practicaba un primitivo "periodismo oral". Pensemos en espacios similares en España, cual fueron los mentideros de algunas ciudades españolas en la Edad Moderna: la Plazuela de León en Madrid, las Losas de Palacio, en el desaparecido Alcázar, o las también desaparecidas gradas del convento de San Felipe el Real en una de las esquinas de la Puerta del Sol. En Londres, París y otras ciudades europeas a lo largo del siglo XVIII la esfera pública moderna se fue conformando merced al impulso de la proliferación de la cultura impresa en una variedad de nuevos espacios públicos. Algunos como los cafés surgieron impulsados por el surgimiento de nuevos hábitos de consumo. Otros, como los clubs, las sociedades o las academias, como consecuencia de la expansión de culturas políticas y artísticas

\footnotetext{
${ }^{5}$ Adrian Johns: The Nature of the Book: Print and Knowledge in the Making, Chicago, University of Chicago Press, 1998; David Zaret: Origins of Democratic Culture: Printing, Petitions, and the Public Sphere in Early-Modern England, Princeton, N.J., Princeton University Press, 2000; Gillian Russell: Women, Sociability and Theatre in Georgian London, Cambridge, Cambridge University Press, 2007.

${ }^{6}$ Christian Speck: The String Quartet: from the Private to the Public Sphere, Turnhout, Brepols, 2016.
} 
alternativas. España no quedó al margen de ese proceso. Una emergente esfera pública se fue articulando en las Reales Academias y las Sociedades Económicas de Amigos del País, en buena medida patrocinadas por la nueva clase político-administrativa de la monarquía borbónica, que la utilizaba como medio de promoción social y de vía de acceso al poder. Igual puede decirse de las tertulias, los saraos, los salones literarios y los primeros cafés, espacios en los que se practicaba una sociabilidad más abierta que permitía una discreta cohabitación entre nobleza y burguesía ${ }^{7}$. Ahora bien, salvo los cafés, la mayoría de los espacios mencionados no eran plenamente públicos, en muchos el acceso era restringido, como ocurriera en los clubs ingleses. Incluso algunos limitaban el debate debido a haber sido creados con perfiles ideológicos determinados. Entonces, ¿cuándo y dónde encontramos una esfera totalmente pública en España y cuál fue el papel jugado por la música en el proceso de su configuración y en su mantenimiento como espacio de congregación de comunidades de opinantes?

Una pista temprana sobre el momento y sus características la encontramos en un artículo del perspicaz Mariano José de Larra titulado "¿Quién es el público y dónde se encuentra?” publicado en $1832^{8}$. Larra formula su pregunta consciente de estar escribiendo para una comunidad pública de lectores opinantes y su intención es disertar, con su característico espíritu mordaz, sobre la composición de ese colectivo. Su preocupación es saber si en verdad existe una esfera pública en el momento en que vive y cuáles son sus características. Para ello se pasea por las calles de Madrid un domingo, el mejor día para encontrar público, grupos de personas que están participando en actividades diferentes a las que realizan en la rutina de su vida diaria. Su mirada crítica encuentra a gente que sale de las iglesias, que se aglomera en los paseos, que después hace visitas, "la mayor parte inútiles" y que, cuando hay, va a los toros. Esos son los lugares y las actividades que aglomeran a la mayor parte de los madrileños para relacionarse públicamente, para ver y ser vistos, espacios y rutinas que el autor ironiza como poco provechosas, expresión de una sociedad más bien anclada en la tradición y el adocenamiento. Pero el "pobrecito hablador" menciona otros espacios que le resultan más sugestivos, a los que presta más atención y que sin duda constituyen una esfera pública de opinantes en consonancia con el modelo de Habermas. Estos son en primer lugar los teatros y, aún con más consistencia, los cafés. En el teatro encuentra un público activo que se halla como en su hogar:"Esta parece ser su casa, el templo donde emite sus

\footnotetext{
${ }^{7}$ María de los Ángeles Pérez Samper: "Espacios y prácticas de sociabilidad en el siglo XVIII: tertulias, refrescos y cafés de Barcelona”, Cuadernos de Historia Moderna, 26, 2001, pp. 11-55.

${ }^{8}$ El Pobrecito Hablador. Revista Satírica de Costumbres, por el Bachiller don Juan Pérez de Munguía (seud. de Mariano José de Larra), n. ${ }^{\circ}$ 1, agosto 1832
} 
oráculos sin apelación". Allí opinan de si esta obra es buena, de si estaría mejor en prosa, de si el autor no sabe versificar o si el actor declama mal. Uno ensalza la obra afirmando que "nada se ha hecho mejor de Moratín acá", otro sin embargo la encuentra falta de chispa, fría, de moral insípida y culpa al clasicismo de acarrear la muerte del genio. Para Larra esa comunidad de opinantes, mayormente fatuos, es aún más numerosa en los cafés. Los describe como lugares más bien destartalados, oscuros y estrechos, pero llenos de actividad oratoria. En una mesa cuatro militares ponderan sobre faenas taurinas $\sin$ apenas saber nada de tauromaquia. "En otra, cuatro leguleyos que no entienden de poesía, se arrojan a la cara en forma de alegatos y pedimentos mil dicterios acerca del género clásico y del romántico". Más allá, cuatro poetas "que no han saludado el diapasón” ponderan sobre las calidades de esta frente a aquella bien conocidas divas de la ópera del momento. En suma, el relato de Larra nos dibuja una variedad de espacios con sus respectivos públicos. Conjuntos diversos que actúan en lugares específicos de la vida de la ciudad. Una esfera pública que no es ahistórica y que además tiene peculiaridades nacionales.

Por tanto, para entender la esfera pública española hay que estudiar esos espacios y, sobre todo, esos públicos. En las páginas que siguen vamos a escudriñar el quehacer de uno de esos colectivos y de los espacios en que se conformó9. Me refiero al público musical, a cómo alrededor de la música o en la música misma se conformaron comunidades de opinantes, creadores e intérpretes que contribuyeron a la configuración de la esfera pública del siglo XIX creando una comunidad específica que hoy conocemos como "el público musical”. ¿Quién integró ese público musical? ¿Cuándo y cómo surgió? ¿En qué espacios proliferó? ¿Qué medios utilizó para constituirse como parte de la esfera pública?

\section{La figura del amante de la música, entre el Antiguo y el Nuevo Régimen}

De nuevo el relato de Larra nos ayuda a encontrar la pista que nos conduce a la caracterización de ese público en el caso español. Recordemos su irónica referencia al grupo de poetas sentados en la mesa de un café emitiendo opiniones vehementes sobre "el punto poco tratado de la diferencia de la Tossi y de la Lalande" ${ }^{0}$. Según Larra, apenas sabían nada de música,

\footnotetext{
${ }^{9}$ Harold Love: "How Music Created a Public", Criticism, 46, 2, Spring 2004, pp. 257-271; Michael Chanan: From Haendel to Hendrix: The Composer in the Public Sphere, Londres, Verso, 1999.

${ }^{10}$ La soprano Adelaide Tosi (1800-1855) conoció la fama en Milán, su ciudad natal, desde donde desarrolló una brillante carrera operística cuyos principales escenarios fueron Milán, Nápoles, Madrid y Londres. Henriette Méric Lalande (1798-1867) nació en el seno de una familia musical francesa -su padre era director de orquesta-. Inició su carrera como soprano en Francia y ganó su fama en Italia bajo
} 
pero estaban a punto de llegar a las manos debatiendo sobre las cualidades de la voz de las dos grandes divas del momento. Ramón Mesonero Romanos también recoge esta confrontación entre opinantes en sus Escenas Matritenses al referirse al crecimiento de un público que "no se conformaba ya con artistas medianos" y que "al concluirse el año cómico de 1831 con la despedida de la señora Adelaida Tossi, faltó poco para que los partidos encontrados de Tossistas y Lalandistas consiguiesen sembrar una eterna discordia en nuestra sociedad madrileña" ${ }^{11}$. Exageraciones aparte, lo que estos comentarios reflejan es la existencia de grupos de personas que debatían públicamente, en los cafés, en las lunetas y los pasillos de los teatros, en los salones, en los paseos y en la prensa. Aquí aparece el principal elemento de la contribución de la música a la configuración de moderna esfera pública burguesa: la aparición de un público opinante representado en la figura del "amante de la música"-el entendido, el melómano o el diletante, como se les denominó en la época-. Un colectivo que se diferenciaba del tradicional oyente y que fue el creador de una de las diversas comunidades que la esfera pública española.

El "amante de la música" es una figura de la Modernidad ${ }^{12}$. Aunque la música tuviera una dimensión pública en la Edad Moderna, en las iglesias, las fiestas, las representaciones teatrales o la ópera, los oyentes de la música no se identificaban a sí mismos como una comunidad. El oyente o incluso el antiguo amante de la música dependían del patronazgo, ya fuera cortesano-aristocrático o eclesiástico y, por ello, constituían una minoría aislada. Serían los asistentes regulares a la variedad de eventos musicales que surgieron en diversas partes de Europa desde finales de la Edad Moderna quienes llegarían a reconocerse entre sí y a compartir una identidad de grupo, a cada integrante de aquellos colectivos se les conoció con diferentes nombres en distintos lugares de Europa. En Gran Bretaña se les llamó los music lovers, en Alemania musikfreund, en Francia amateurs de musique y en España, como ya se ha dicho, diletantes en el siglo XIX, y más comúnmente amantes de la música. Un cúmulo de grupos cuya extracción social en sus orígenes desde finales del siglo XVIII procedió de segmentos nobiliarios y burgueses, pero que, en la segunda mitad del XIX, llegaría a integrar a sectores de las clases trabajadoras a través de las asociaciones que promovieron las bandas de música y las agrupaciones corales.

\footnotetext{
el patronazgo del tenor español Manuel Vicente del Pópulo García. Méric-Lalande actuó en diversos países europeos estrenando óperas de Bellini y alcanzando un alto grado de notoriedad.

${ }^{11}$ Ramón de Mesonero Romanos: "La Filarmonía", Escenas Matritenses por el Curioso Parlante, Madrid, Imprenta y Librería de Don Ignacio Boix, 4. ${ }^{a}$ ed., p. 177.

12 H. Love: "How Music...", p. 260.
} 
El amante de la música era partidario, animador y consumidor activo de ese arte en su manifestación pública. Este público se aprecia en Inglaterra, Francia y otras partes de Europa desde mediados del XVIII en una amplia variedad de espacios que fueron desde las coffeehouses londinenses a los espacios domésticos de las emergentes burguesías nacionales ${ }^{13}$. El momento de su aparición en España constituye un primer tema objeto de debate. Los artículos citados de Larra y Mesonero indican la inequívoca existencia de comunidades de amantes de la música en Madrid hacia 1830. Mesonero va más allá, cita el año 1816, con el estreno de La italiana en Argel, como el momento de la recuperación filarmónica tras la crisis creada por la guerra en la capital. Esa actividad, según Mesonero, continuó en los años veinte y cristalizó en los treinta, momento en el que se sitúa su sátira hacia los que él calificara como "filarmónicos de salón", ejemplares de la incuestionable existencia de comunidades de amantes de la música. Cabe preguntarse, y con esto hago mi primera propuesta de investigación, si los gérmenes, o siquiera los primeros ejemplos de un público musical no podrían encontrarse en los conciertos que patrocinaron algunas Sociedades de Amigos del País, o en la variedad de actividades musicales de los teatros, de las academias, de los salones, saraos y tertulias de las clases altas, o incluso en los primeros cafés abiertos en Barcelona y Cádiz a finales del XVIII ${ }^{14}$.

En años recientes la investigación de la transición entre siglos ha avanzado notablemente. Alberto Hernández Mateos ha detectado la existencia de una activa comunidad de opinantes musicales, tanto profesionales como aficionados, en las páginas del Diario de Madrid entre 1796 y $1804^{15}$. En su estudio sobre el pensamiento musical de Antonio Eximeno, Hernández Mateos también ilustra diversos episodios y circunstancias que indican la existencia de un incipiente público musical en España desde el último tercio del siglo XVIII ${ }^{16}$.

${ }^{13}$ Carl Dahlhaus: Nineteenth-century Music, Berkeley, University of California Press, 1989, pp. 48-49.

14 Sobre las actividades relacionadas con la música de algunas Sociedades de Amigos véase Pedro Ruiz Torres: Reformismo e Ilustración, vol. 5 de la Historia de España, dirigida por Josep Fontana y Ramón Villares, Barcelona, Crítica-Marcial Pons, 2008, p. 475; Jon Bagüés: "La música y la danza en los proyectos pedagógicos de la Real Sociedad Bascongada de Amigos del País", Reçerca Musicológica, 8, 1988, pp. 117-131. Sobre las tertulias y primeros cafés, además del citado trabajo de María de los Ángeles Pérez Samper, véase Arturo Morgado García: "La cultura gaditana del siglo XVIII", Manuel García: de la tonadilla escénica a la ópera española (1775-1832), Alberto Romero Ferrer y Andrés Moreno Mengíbar (eds.), Universidad de Cádiz, 2006.

${ }^{15}$ El debate lo provocó la publicación de un anuncio sobre la traducción de Del origen y reglas de la música, y de la Duda de Antonio de Eximeno. Véase Alberto Hernández Mateos: "Maestrazos de contrapunto, rutineros maquinales, chabacanos seguidilleros. La recepción polémica del pensamiento de Antonio Eximeno en el Diario de Madrid (1796-1804)", Revista de Musicología, 36, 2013, pp. 189-224. Sobre la actividad musical detectada en el Diario de Madrid a finales del XVIII ver la compilación de noticias seleccionadas por Yolanda F. Acker: Música y danza en el Diario de Madrid (1758-1808): noticias, avisos y artículos, Madrid, Centro de Documentación de Música y Danza, 2007.

${ }^{16}$ Alberto Hernández Mateos: El pensamiento musical de Antonio de Eximeno, Universidad de Salamanca, Ediciones Universidad de Salamanca, 2013, pp. 343-348. 
Esta actividad se transluce en la eclosión de un activo mercado de partituras, instrumentos y tratados en gran medida aún por investigar. Oriol Brugarolas Bonet ha estudiado el caso de Barcelona, donde a partir de 1792 se detecta una intensificación del comercio de partituras que evidencia el alto desarrollo de la actividad y la cultura musical de la ciudad y muestra que, al menos desde 1814, España formaba parte de una red de distribución de partituras europea ${ }^{17}$. Los trabajos de Miguel Ángel Marín y José Máximo Leza sobre los repertorios orquestales durante el último tercio del XVIII referidos la obertura, la sinfonía, el concierto, la consolidación de la sonata y el surgimiento del cuarteto de cuerda en el contexto del patrocinio privado de algunas casas nobiliarias confirman la existencia de un público musical $^{18}$. Falta por delimitar, y aquí es donde han de apuntar las investigaciones futuras, las características de ese público temprano y si estas encajan en el modelo europeo del amante de la música de la modernidad.

Harold Love considera que ciertas familias de músicos, como los Bach, los Purcell o los Mozart, pudieron constituir las primeras comunidades de amantes de la música en Europa porque transmitían de generación en generación, en el marco de un sistema gremial, las habilidades de la musicalidad profesional ${ }^{19}$. Imaginemos algunas familias de músicos españoles profundamente imbuidas en una vida dedicada a la música, como fue el caso de los Albéniz: Mateo, el padre (1795-1855), maestro de capilla, organista y compositor; Pedro, el hijo (1855-1831), estudiando en París, recibiendo consejos de los grandes maestros del momento y culminando una carrera como maestro de Isabel II y virtuoso pianista de los salones la sociedad de buen tono isabelina. Dos generaciones de músicos que constituyen un ejemplo paradigmático de la transición de la Edad Moderna a la Contemporánea. Metiéndonos de lleno en el siglo XIX los ejemplos se multiplican: los Sarasate padre e hijo, el padre Miguel Sarasate Juanena (1818-1888) ejerciendo de músico mayor en varios regimientos en diversos lugares de España y educando y apoyando a su hijo hasta convertirlo en uno de los grandes virtuosos de la historia; los Ferrer Esteve de Fujadas o los Arcas, que dieron varias generaciones de guitarristas de renombre internacional, en el caso de los Arcas partiendo de un promotor que no era profesional, pues Juan Arcas padre no era más que un simple aficionado.

\footnotetext{
17 Oriol Brugarolas Bonet: "El comercio de partituras en Barcelona desde 1792 y 1834: de Antonio Chueca a Francisco Bernareggi", Anuario Musical, 71, 2016, pp. 163-178.

${ }_{18}$ Miguel Angel Marín: "Escuchar la musica: la academia, el concierto y sus publicos", La Musica en el siglo XVIII, Historia de la Musica en Espana e Hispanoamerica, vol. 4, José Maximo Leza (ed.), Madrid, Fondo de Cultura Economica, 2014, pp. 461-465; Josep M. Vilar i Torrens: "La sinfonía en Cataluña, 1760-1808", La música en España en el siglo XVIII, Malcolm Boyd y Juan José Carreras (eds.), Madrid, Cambridge University Press, 2000, pp. 183-197.

${ }^{19}$ H. Love: "How Music...", p. 260.
} 
Sin olvidar a las familias ligadas al mundo de la ópera, cual fue el caso mejor conocido del clan creado por el carismático Manuel (del Pópulo) García, quien además de erigirse en uno de los tenores favoritos de Rossini, tuvo dos hijas que fueron sopranos famosas y un hijo que pasó por ser el maestro de canto más influyente del siglo XIX ${ }^{20}$.

Ahora bien, las familias de músicos constituyeron comunidades no completamente públicas. Además, habría que dilucidar cuántas, de entre los ejemplos señalados, pudieran ser consideradas como más representativas de la persistencia de estructuras y prácticas gremiales y cuáles estarían más próximas a la profesionalización característica de la modernidad musical.

\section{Nuevos espacios públicos, sociabilidad y modernidad}

El moderno público musical hay que situarlo en la variedad de espacios públicos que fueron creándose a lo largo del siglo XVIII propulsados por el surgimiento de nuevas prácticas de sociabilidad y por los impulsos de la modernidad cultural. Para medir la contribución de la música a la configuración de la esfera pública española del siglo XIX se van a examinar seis de las ocho principales comunidades de amantes de la música que fueron surgiendo durante aquel periodo. Estas serían: el público de los salones, tertulias, gabinetes y establecimientos musicales, el público de los cafés, el público de las nuevas agrupaciones o sociedades artísticas y musicales, los públicos de la ópera, la zarzuela y los conciertos sinfónicos, los integrantes de las agrupaciones de bandas de música civiles y, finalmente, los miembros de las agrupaciones corales y orfeonistas. Dejamos aparte por razones de espacio las comunidades integradas por la crítica y publicística que se desarrolló a lo largo del período isabelino y que articularía un nuevo espacio comunicativo, así como la surgidas alrededor de las nuevas instituciones educativas que influirían en los procesos de profesionalización de los músicos. Todos estos públicos constituyeron un elenco de oyentes, opinantes, compositores e intérpretes que incluyó un amplio espectro social desde las clases altas hasta las trabajadoras con un fuerte componente de segmentos sociales intermedios.

\section{El público de los salones, tertulias, gabinetes y establecimientos musicales}

Una buena parte de la actividad musical de las familias transcurrió en el seno de sus hogares, en espacios que constituían una transición entre lo público y lo privado. El salón, desde los palacios aristocráticos al modesto

\footnotetext{
20 Sobre este caso véase Andrés Moreno Mengíbar: "Manuel García en perspectiva", Manuel García: de la tonadilla..., p. 107 y ss.
} 
gabinete de las familias pequeño burguesas, constituyó el espacio por antonomasia de las modernas comunidades de amantes de la música. Cada país creó su propio término para definir este fenómeno, desde la Hausmusisk alemana hasta la tertulia del mundo hispano. En la tertulia o reunión de salón, además de la discusión política, el debate literario o el burdo chismorreo, se practicó la primera forma de concierto moderno como acto estético y social. En los salones, con la mujer como intérprete principal, se concentraron los primeros grupos de individuos reunidos de forma semipública o totalmente pública con el fin de escuchar música por placer, de opinar sobre lo interpretado y de ritualizar ese acto de sociabilidad hasta convertirlo en un símbolo de distinción social.

En todo el mundo occidental la música de salón o parlour music conoció su apogeo a lo largo del siglo XIX, sin embargo, sus primeras manifestaciones en el norte y centro de Europa se localizan en la primera mitad del XVIII. ¿Dónde se sitúa el caso español en este desarrollo? El cuándo sigue siendo el primer aspecto complicado de esta historia. María Aurelia Díez Huerga ha proporcionado la investigación más completa de las diversas dinámicas regionales de la historia del salón aristocrático y burgués a partir de la década de $1830^{21}$. Existen otros trabajos en su mayor parte referidos a casos concretos de familias notables, pero en su mayor parte no cruzan la frontera entre los siglos XVIII y XIX. ¿Llegaron a albergar veladas con música de cámara con audiencias entregadas al placer de escuchar y a la acción de opinar los salones de Alba, Osuna-Benavente,Villahermosa, Campo Alange o Montijo en época de Carlos IV? ¿Existieron "filarmónicos de salón” antes de que Mesonero Romanos los inmortalizara con su ironía?

Cierto que la reconstrucción de la historia de la vida de los salones es harto difícil, especialmente en lo que se refiere al periodo de su preludio. Desde la segunda mitad del siglo XIX contamos con la abundante información proporcionada por los cronistas de sociedad, pero las fuentes documentales son más escasas a medida que retrocedemos en el tiempo. Dicho esto, el estudio de la historia del salón burgués es complicada pero no imposible si combinamos metodologías y enfoques de la clásica historia social y de la nueva historia cultural. Una posible vía es la reconstrucción de historias familiares. María Jesús González Sinde aporta un excelente ejemplo en su estudio sobre los salones de dos generaciones de la célebre familia de pintores madrileños, los Madrazo, desde los tiempos de Federico Madrazo en los años treinta del XIX hasta principios del siglo XX. En su historia, basada en la consulta de una variedad de fuentes privadas y visuales,

\footnotetext{
${ }^{21}$ María Aurelia Díez Huerga: "Salones, bailes y cafés: costumbres socio-musicales en el Madrid de la Reina Castiza (1833-1868)", Anuario Musical, 61, 2006, pp. 189-210; id.: "La música en los salones del Oviedo decimonónico: el mundo salonier en la ciudad de Clarín", Anuario Musical, 70, 2015, pp. 101-116.
} 
las mujeres son los agentes centrales en la creación de un entramado de relaciones de sociabilidad en el que participaron artistas plásticos, famosos compositores, instrumentistas y simples oyentes, todos ellos integrando una comunidad de amantes de la música cuya actividad transcendió a la vida cultural de los diversos lugares donde existieron los salones ${ }^{22}$.

Los testimonios visuales pueden constituir una fuente útil para conducirnos a grupos familiares o individuos que patrocinaron actividades musicales y crearon comunidades de amantes de la música. Richard Leppert investigó, clasificó y analizó pinturas de la Inglaterra del siglo XVIII como vía para historiar la formación de comunidades culturales, algunas de ellas ligadas a la música ${ }^{23}$. Es un trabajo arduo, pero de gratos resultados. En España se han identificado algunos retratos de aristócratas y miembros de la realeza con motivos relacionados con la música, pero el tema necesita ser investigado con mayor profundidad. Más frecuentes se hacen los retratos de familias de la burguesía a lo largo del siglo XIX. Estos suelen presentar escenas de grupo en las que un personaje, casi siempre femenino, aparece sentado junto al piano con la mano derecha sobre el teclado simulando arrancar unas notas. Algunas de estas familias, como la del banquero Jorge Flaquer pintada por Joaquín Espalter y Rull o la de Juan Manuel de la Pezuela obra de José Elbo, son menos dificiles de investigar. Flaquer fue un destacado hombre de negocios de su época (Ilustración 1). Pezuela pertenecía a una familia de notables e hizo carrera en política y en el mundo de las letras (Ilustración 2). Ambas familias ejemplifican el valor simbólico que adquirió la música como indicador de distinción para los grupos dominantes del siglo XIX. Ambas contrataron profesores para educarse musicalmente y, como reflejan sus representaciones, acogieron en su hogar tertulias y veladas musicales que pueden ser investigadas escudriñando en sus documentos privados, en los públicos que depositaron ante notario y, en algunos casos, en las notas de sociedad de la prensa de la época. Los testimonios literarios, las memorias, los diarios y la abundante producción impresa referida a la urbanidad, la etiqueta y la elegancia son también instrumentos de enorme utilidad para esta tarea de reconstrucción de la historia del salón decimonónico. Pensemos en el ejemplo del marqués de Molíns quien, en sus recuerdos biográficos sobre Bretón de los Herreros, incluye abundante información sobre diversas tertulias madrileñas como

\footnotetext{
${ }^{22}$ María Jesús Fernández Sinde: "Imagen y usos sociales de la música: presencia femenina en los salones y estudios de pintores españoles decimonónicos. La saga de los Madrazo y su entorno", Quadrivium, Revista Digital de Musicología, Asociación Valenciana de Musicología, 5, 2014.

${ }^{23}$ Richard D. Leppert: Music and Image: Domesticity, Ideology, and Socio-Cultural Formation in Eighteenth-Century England, Cambridge, Cambridge University Press, 1988.

${ }^{24}$ Molíns, Marqués de (Mariano Roca de Togores): Bretón de los Herreros: recuerdos de su vida y de sus obras, Madrid, Imprenta y Fundición de M. Tello, 1883, p. 39 y ss.
} 


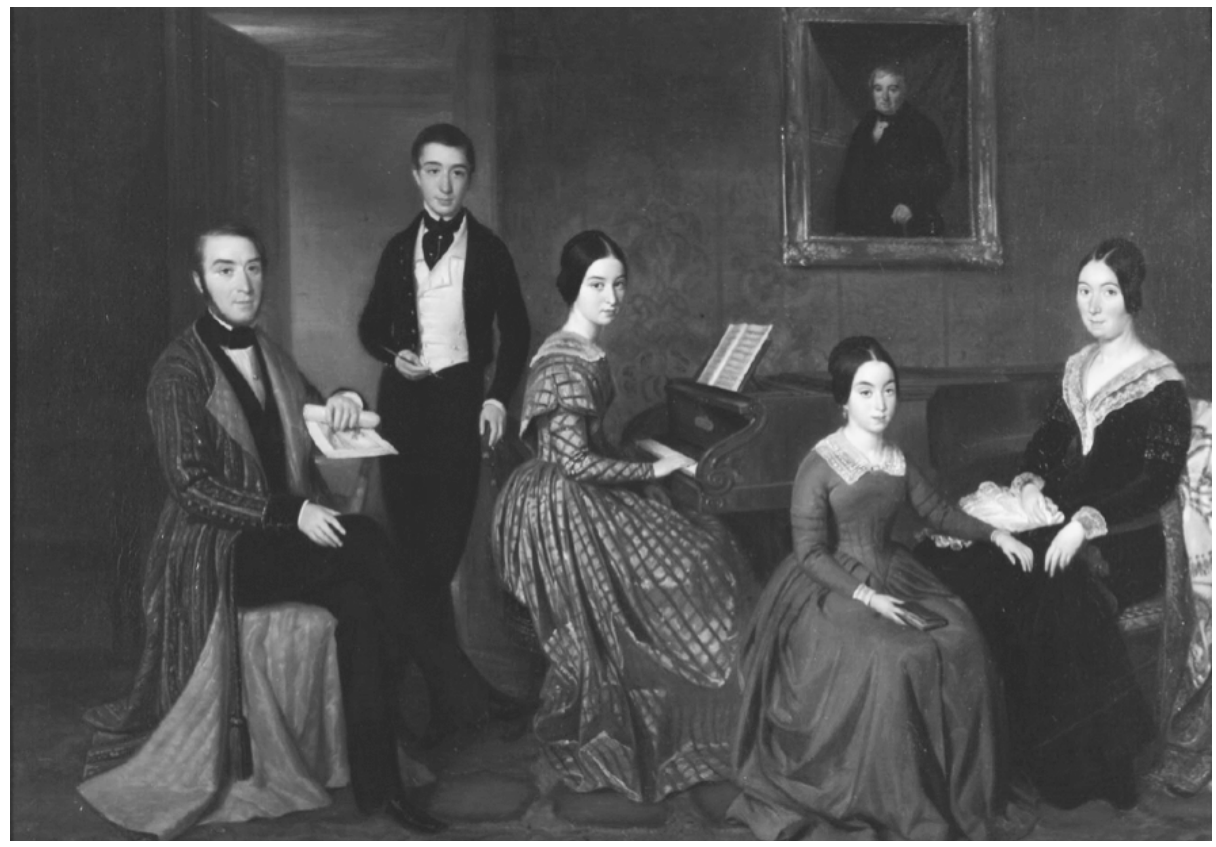

Ilustración 1. Joaquín Espalter y Rull: La familia del banquero Jorge Flaquer (1840-1845)

(Museo Nacional del Romanticismo, Madrid)

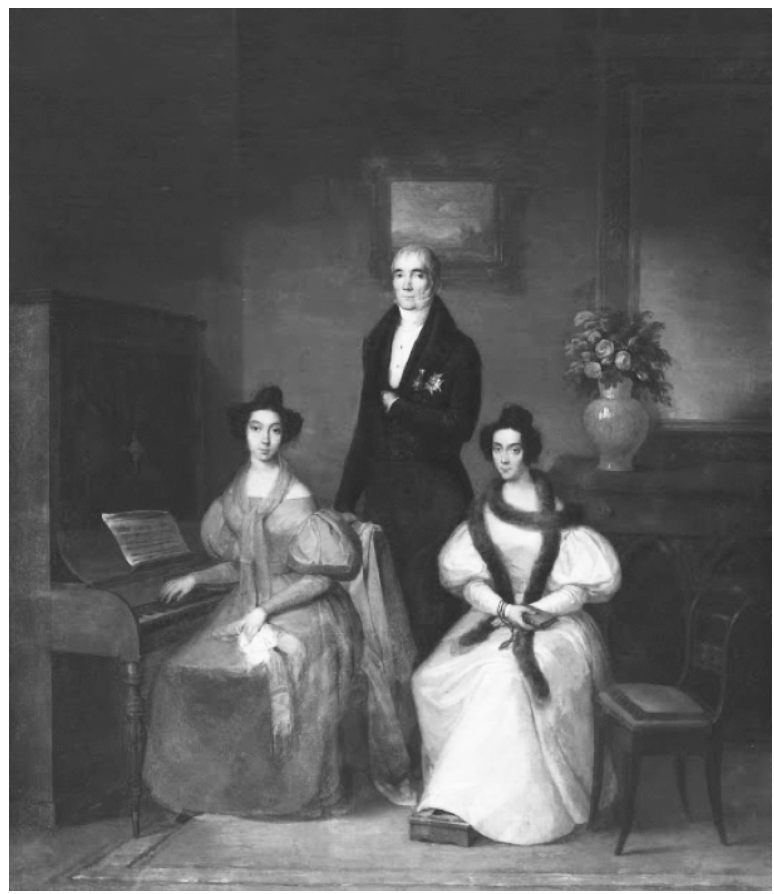

Ilustración 2. José Elbo Peñuelas: La Familia de Juan Manuel de la Pezuela Madrid (Museo Nacional del Romanticismo, Madrid) 
la del arquitecto Mariátegui, un posible primer testimonio de sociabilidad con actuación musical a principios de la década de $1830^{24}$.

En fin, el salón aristocrático o burgués, con su carácter semipúblico o público, constituyó el espacio por excelencia de las tempranas comunidades de amantes de la música y, lo que es más importante, quienes participaban, quienes los promovían fueron a su vez consumidores y promotores de la profesionalización del mundo de la interpretación. Se hizo más frecuente el contratar a músicos profesionales para realzar la calidad de las veladas. Al mismo tiempo ese público conformó una creciente clientela de los primeros almacenes musicales. En la década de 1840 ya existían en Madrid, Barcelona y otras ciudades, establecimientos musicales bien asentados como los almacenes de Lodre y de Carrafa en Madrid (carrera de San Jerónimo y calle del Príncipe) o los de Sebastián Iradier y Conde-Martín Salazar. Ambos aspectos, la contribución del salón burgués a la profesionalización y la historia del almacén musical han sido poco estudiados ${ }^{25}$. En suma, la tertulia musical de salón constituyó la primera contribución de la música a la conformación de la esfera pública y al fomento de la modernidad desplegando su energía y actividad a la diversidad de nuevos espacios públicos y actividades de sociabilidad surgidos en la época de la revolución liberal.

\section{El público de los cafés}

El café fue el primer espacio plenamente público en el que comunidades más amplias de amantes de la música hallaron un lugar de encuentro. En Inglaterra los primeros conciertos públicos organizados de una manera regular, aunque con un público muy limitado, se dieron en las tabernas y las coffeehouses en la primera mitad de XVIII ${ }^{26}$. En España sabemos que los primeros cafés se abrieron en Cádiz, en Barcelona y en otras ciudades portuarias en la segunda mitad del siglo XVIII ${ }^{27}$. La primera aparición de actividades musicales documentada data de 1817. El dato procede de Mariano Soriano Fuertes quien, al referirse a los inicios de la carrera de Anselmo Clavé, menciona que desde aquella fecha se habían introducido los conciertos de canto en algunos cafés de Barcelona ${ }^{28}$. ¿Existieron actuaciones

\footnotetext{
25 Sobre los inicios del consumo de productos musicales véase Victoria Alemany Ferrer: "La construcción de pianos en Valencia hasta inicios del siglo XX", Anuario Musical, 62, 2007, pp. 335-364; Begoña Gimeno Arlanzón: "Sociedad, cultura y actualidad artística en la España de fines del siglo XIX a través de las publicaciones periódicas musicales: Zaragoza y la revista El Correo Musical 1888 (I)", Anuario Musical, 60, 2005, pp. 169-215; Begoña Gimeno Arlanzón: "Sociedad, cultura y actualidad artística en la España de fines del siglo XIX a través de las publicaciones periódicas musicales: Zaragoza y la revista El Correo Musical, 1888 (II)", Anuario Musical, 61, 2006, pp. 211-262.

${ }^{26}$ H. Love: "How Music ...", p. 263.

27 Antonio Bonet Correa: Los cafés históricos, Madrid, Cátedra, 2012.

${ }_{28}$ Mariano Soriano Fuertes: Memoria sobre las sociedades corales en España, Barcelona, Establecimiento tipográfico de D. Narciso Ramírez y Rialp, 1865, p. 33.
} 
musicales en épocas anteriores? Teniendo en cuenta que Soriano se refiere al canto no es descabellado pensar que estas fueran precedidas de interpretaciones instrumentales. Es un aspecto de la temprana historia de los cafés que requiere ser investigado. Emilio Casares afirma que en Madrid y Barcelona los cafés concierto de mediados de siglo ofrecieron conciertos sinfónicos que no podían escucharse ni en teatros ni en otros espacios de actividad musical ${ }^{29}$. Es decir, que el café pudo jugar un papel en la historia de la llegada del concierto moderno en España que muchos investigadores no han tenido en cuenta. Otro aspecto importante de la contribución de los cafés a la creación de un público musical fue la aparición del café cantante y en la segunda mitad del siglo de los teatros por horas un híbrido de café y teatro cuya historia y carácter es todavía objeto de debate ${ }^{30}$.

\section{Sociedades artísticas y musicales}

El público de las sociedades artísticas y musicales se consolidó en la época isabelina tras el impase de las guerras Napoleónicas, pero sus raíces están en las primeras formas de asociacionismo surgidas sobre todo en la época de Carlos III ${ }^{31}$. Como ya se ha señalado, es mucho lo que queda por investigar en lo referente a la actividad musical de las primeras Sociedades Económicas de Amigos del País y de las Academias y delimitar las continuidades, si las hubo, con el rebrote asociacionista a partir de 1820. María Aurelia Díez Huerga ha apuntado cómo el final del absolutismo abrió paso a una expansión de la voluntad asociativa protagonizada en su mayor parte por la burguesía y animada por su credo liberal ${ }^{32}$. Las instituciones surgidas en este impulso constituyeron una parte del entramado de espacios que integrarían la esfera pública española, comenzando con los casinos, el más antiguo datado en 1814, y siguiendo con los ateneos, los liceos, los institutos y una multiplicidad de agrupaciones de carácter secundario y vida efimera. Los casinos como agrupaciones de carácter recreativo, aunque también con un contenido cultural, fueron piezas esenciales de la articulación de la sociedad de buen tono, especialmente en el mundo de las provincias ${ }^{33}$. Los ateneos

\footnotetext{
29 Emilio Casares Rodicio: "La música del siglo XIX. Conceptos fundamentales", La música española en el siglo XIX, E. Casares Rodicio y Celsa Alonso González (eds.), Oviedo, Universidad de Oviedo, 1995, pp. 44-48.

30 Sobre estos espacios y su relación con la música puede verse el artículo de Enrique Mejías en este mismo dosier.

${ }^{31}$ María Zozaya Montes: "El origen dieciochesco de los casinos españoles y su raíz italiana", Ocio y vida cotidiana en el mundo hispánico moderno, Francisco Núñez Roldán (coord.), 2007, pp. 617-630.

32 M. A. Díez Huerga: "Las sociedades musicales en el Madrid de Isabel II (1833-1868)", Anuario Musical, 58, 2004, pp. 253-277.

${ }^{33}$ Rafael Villena Espinosa y Ángel Luis López Villaverde: "Espacio privado, dimensión pública: hacia una caracterización del casino en la España contemporánea”, Hispania, 214, 2003, p. 444; M. Zozaya: El Casino de Madrid, orígenes y primera andadura, Madrid, Casino de Madrid, 2002.
} 
tuvieron un carácter fundamentalmente cultural, científico y académico y, hasta las reformas de la enseñanza de finales del XIX y principios del XX, constituyeron la espina dorsal de la vida intelectual del país. Ambas instituciones promovieron una notable variedad de actividades musicales y contribuyeron enormemente a la formación de un público musical. Una buena parte de esa historia está todavía por hacer. Como también lo está la de otro tipo de institución que tuvo, al menos en Madrid, un momento de brillantez y un tan rápido como sorprendente declive, me refiero a los liceos artísticos ${ }^{34}$.

Los liceos también fueron un fenómeno nacional, aunque a diferencia de los casinos tuvieron una razón de ser cultural y una historia muy desigual. En buena medida los liceos surgieron como una prolongación pública de los salones, acogiendo a un público selecto de la burguesía y la nobleza integrante de la sociedad de buen tono. Gracias al trabajo de Aránzazu Pérez Sánchez conocemos bien la historia del Liceo de Madrid y sabemos que fue una institución fundamental en la creación de uno de los primeros públicos musicales en la capital ${ }^{35}$. Una peculiaridad del Liceo Artístico y Literario de Madrid (1837-1851) y de otros en provincias fue la activa participación de mujeres. Además de las sesiones de competencia de los jueves que incluyeron interpretaciones musicales, premios y homenajes, el Liceo madrileño organizó unos sesenta conciertos entre 1841 y 1846. Algunos de estos tuvieron como invitados a estrellas de la ópera del momento como Juan Bautista Rubini y Manuela Oreiro y patrocinaron algunos estrenos como la ópera Boabdil de Baltasar Saldoni, con el recurrente fin de promover una ópera nacional. Sabemos que toda esta energía tuvo sus momentos de gloria con las actuaciones de Franz Liszt en 1844-1845 ${ }^{36}$ y Sigismond Thalberg en 1848 y que todo su entramado se desmanteló de forma más bien súbita tal vez a consecuencia de la nueva legislación introducida en 1849 por el Reglamento de Teatros ${ }^{37}$.

\footnotetext{
34 Sobre la historia del asociacionismo musical en España ver el volumen monográfico de Cuadernos de Música Iberoamericana, 8-9, 2001; también los artículos sobre Sánchez Allú publicados en la Revista de Musicología, vol. 38, 2, 2005, en particular Josefa Montero: "Catedral y música civil en torno a Martín Sánchez Allú (1823-1858)", pp. 499-527 y Alberto Hernández Mateos: "Modernización musical y periferia en la España isabelina. Un caso de estudio: la Escuela de San Eloy y la Salamanca de Martín Sánchez Allú", pp. 465-497.

35 Aránzazu Pérez Sánchez: El liceo artístico y literario de Madrid (1837-1851), Madrid, Fundación Universitaria Española, 2005.

36 Sobre la gira de Franz Liszt en la península ibérica, en la que tuvieron un papel fundamental los liceos, casinos y otras sociedades artísticas y musicales, véase Antonio Simón: Liszt en la península ibérica. Su discurso musical y su reflejo en los medios, tesis doctoral, Universidad de Málaga, 2015.

${ }^{37}$ Sobre la visita de Liszt a España ver Antonio Simón Montiel: Liszt en la península ibérica. Su discurso musical y su reflejo en los medios, tesis doctoral, Publicaciones y Divulgación Científica, Universidad de Málaga, 2015. El Reglamento de Teatros fue también la causa de la desaparición de otras dos agrupaciones de amantes e intérpretes musicales establecidas en Madrid entre 1830 y 1850: el Instituto Español (1839), enfocado en la promoción de óperas y conciertos que culminó en 1845 con la inauguración de un teatro público y el Museo Lírico (1840), orientado a promoción de la zarzuela.
} 
Muy diferente fue el destino y hasta cierto punto el origen del otro gran liceo conocido en sus orígenes como Liceo Filarmónico de Isabel II, fundado en Barcelona a iniciativa del 14 Batallón de la Milicia Nacional, de orientación liberal moderada. El Liceo de Barcelona fue iniciativa de un grupo de ciudadanos, movidos por su adhesión al liberalismo y su deseo de promocionar la música y el arte dramático, organizando representaciones teatrales y promoviendo la enseñanza teatral y musical. Barcelona desde la segunda mitad del XVIII se estaba consolidando como una ciudad con enorme vocación de modernidad en la que la música jugó un papel esencial. Los promotores del Liceo barcelonés pronto orientaron sus energías a la construcción de un teatro de ópera al estilo de los existentes en otras capitales europeas ${ }^{38}$. Pretendían que fuera el mejor teatro de Barcelona y, por qué no, de España entera, dotado de las más modernas instalaciones, decorado con la máxima elegancia y capaz de competir en aforo con los grandes teatros europeos. El resultado es bien conocido: la inauguración del Gran Teatro del Liceo el 4 de abril de 1847, casi tres años antes de la apertura del Teatro Real de Madrid, que había sido planificado con mucha más antelación para ser el gran teatro nacional de ópera del país. Sabido es que el Liceo de Barcelona albergaría una muy activa comunidad de oyentes y opinantes que en el último tercio del siglo llegó a marcar las pautas de los debates culturales en el seno de las comunidades de amantes de la música en toda España. Baste recordar, en esa época, la actividad de los jóvenes puristas y el sector de los connoisseurs, junto con la bohemia de tono antiburgués asidua a las localidades baratas del galliner. Un público que demandó un repertorio más vanguardista llegando a vencer ciertas resistencias y frenando parcialmente el monopolio de la ópera italiana en los repertorios ${ }^{39}$.

La historia de los orígenes, funcionamiento y aportaciones de los dos Liceos, el de Madrid y el de Barcelona, nos lleva a la compleja y amplia historia de los espacios públicos de mayor transcendencia en la contribución de la música a la configuración de la esfera pública española. Me refiero, evidentemente, a los teatros de ópera y zarzuela y a las primeras salas de conciertos. Pero, ante todo, nos alerta sobre la necesidad de abordar esta historia de una manera integral con una metodología comparativa. Dos son las pautas de investigación que se echan de menos. La primera, una historia del fenómeno liceístico a escala nacional. Hubo varios liceos en Valencia y sabemos de iniciativas similares en Murcia, Alicante, Granada, Zaragoza, Cádiz, Huesca y

\footnotetext{
38 Jaume Radigales: Els orígens del Gran Teatre del Liceu (1837-1847): de la plaça de Santa Anna a la Rambla. Història del Liceu Filharmònic d'Isabel II o Liceu Filodramàtic de Barcelona, Barcelona, Publicacions de l'Abadia de Montserrat, 1998, p. 35.

39 José Ignacio Suárez García: "Polémicas Wagnerianas en el siglo XIX en España”, Anuario Musical, 66,2011 , pp. 181-202
} 
muchas otras ciudades. La tendencia ha sido a estudiarlos de forma local, sin encontrar conexiones entre ellos aun habiendo surgido en un mismo periodo cronológico, promovidos por élites similares y con metas paralelas. La segunda pauta, en la misma línea comparativa, urge un estudio sobre las dinámicas de Madrid y Barcelona en construcción de iniciativas de modernidad en el ámbito de la música. Una historia imprescindible para comprobar si ciertos tópicos asumidos por algunos historiadores y musicólogos tienen fundamento histórico o son meros estereotipos. Por ejemplo, la suposición de que Barcelona, merced al impulso de un nuevo ímpetu nacionalista, abrazara la modernidad burguesa, mientras que en Madrid un rancio conservadurismo aristocrático-cortesano consiguiera ralentizarla o incluso frenarla.

\section{Los públicos de la ópera, la zarzuela y los conciertos sinfónicos}

La ópera fue por excelencia el espacio público de encuentro de la nueva sociedad dominante del siglo XIX, de la sociedad de buen tono, con sus pervivencias y con sus transformaciones y con todo el aparato simbólico y ritual que le otorgaba su peculiar fisonomía. Esa sociedad consiguió mantener el carácter de exclusividad de este espectáculo. La ópera también se convirtió en un símbolo de avance nacional, de modernidad. Como ya se ha dicho, el público de la ópera hasta principios del siglo XX constituyó la comunidad de amantes de la música más activa y, tal vez, más numerosa del público musical español. Su historia es demasiado compleja y extensa como para encajarla en las dimensiones de este artículo. Sí llamaré la atención, una vez más, sobre la necesidad de desarrollar una historia integral de la ópera que toque algunos aspectos aun poco estudiados. A diferencia de otros países europeos, en España se echa de menos una historia cultural de la ópera que sitúe nuestro caso de forma comparada en el contexto internacional. Una historia con perspectiva nacional, aunque utilice casos regionales, que estudie temas como el surgimiento del público musical en grandes y pequeñas ciudades, la competición entre Madrid, Barcelona u otras ciudades por la construcción de teatros de ópera y por la promoción del género, los mecanismos utilizados para mantener la exclusividad social del espectáculo, el papel de los connoisseurs en la conformación de estados de opinión y guerras culturales y el divismo como fenómeno cultural de modernidad. También convendría reconfigurar debates tradicionales a la luz de tendencias metodológicas aportaciones teóricas recientes. Por ejemplo, actualizar la vieja discusión sobre el fracaso o no fracaso de la creación de una ópera nacional a la luz de la abundante literatura sobre nacionalismo aparecida en las dos últimas décadas ${ }^{40}$.

\footnotetext{
${ }^{40}$ De especial importancia en esta línea de investigación son las aportaciones de Juan José Carreras. Véase Juan José Carreras: "Hijos de Pedrell: La historiografía musical española y sus orígenes nacionalistas (1780-
} 
La ópera y el resto de las formas de la música culta, además de los teatros, contaron con otros escenarios públicos, tanto en las dos grandes ciudades como en el resto de los centros urbanos provinciales donde no había teatros especializados. El desarrollo de mayor transcendencia en este sentido sería la aparición del concierto sinfónico como práctica auditiva que envolvía a una comunidad de oyentes, reunidos en un lugar público, con el fin de escuchar y opinar sobre un programa que incluía una o varias obras ejecutadas por una orquesta. Como se ha señalado, esta forma de crear un público musical se originó en el norte y centro de Europa desde principios del siglo XVIII. La historia del concierto sinfónico en España tiene todavía notables lagunas. Es indudable que el concierto como espectáculo de consumo, es decir, como forma de entretenimiento o práctica cultural a la que se accedía pagando una entrada, no se consolida en España hasta la aparición de la Sociedad de Cuartetos de Madrid (1863) y de la Sociedad de Conciertos (1866) ${ }^{41}$. Desde este momento, el posible acceso público a esta actividad musical, comienza a acercar el género instrumental a la sociedad española, pero Madrid no contaría con un local especializado hasta 1884, por iniciativa del músico, hombre de negocios e inventor Antonio Romero y Andía, propietario de la principal tienda de música y editorial musical del Madrid de mediados del XIX ${ }^{42}$. Barcelona, adelantándose a Madrid, abrió el Teatro Lírico-Sala Beethoven, primer local especializado en conciertos de música sinfónica de la ciudad y del país, en 1881. Unos años más tarde, de nuevo tomando la iniciativa a los madrileños, los barceloneses construirían el Palau de la Música Catalana, en este caso como una iniciativa cívica ya ligada al catalanismo cultural y político que se fue haciendo más firme en la Barcelona fin-de-siècle ${ }^{43}$. De manera que el concierto público no se consolidó plenamente en España hasta la segunda mitad del siglo XIX, aunque, una vez más, cabe preguntarse si este desarrollo no estuvo sustentado por un proceso anterior que tendría sus orígenes en las

1980)", Il Saggiatore Musical, 8, 1, 2001, pp. 121-169; id.: "Desde la venida de los fenicios': The National Construction of a Musical Past in $19^{\text {th }}$ century Spain", Musica e Storia, XVI, 2008, pp. 3-14. Para una reciente bien argumentada aportación sobre teatro musical y nacionalismo véase Clinton D. Young: Music Theater and Popular Nationalism in Spain, 1880-1930, Baton Rouge, LSU Press, 2016.

${ }^{41}$ Sobre la Sociedad de Conciertos de Madrid ver Judith Etzion: "Musica sabia': The Reception of Classical Music in Madrid (1830s-1860s)", International Journal of Musicology, 7, 1998, pp. 185-232; Ramón Sobrino Sánchez: "La Sociedad de Conciertos de Madrid, un modelo de sociedad profesional", Cuadernos de Música Iberoamericana, 8-9, 2001, pp. 125-148. Sobre la Sociedad de Cuartetos de Madrid, Ester Aguado Sánchez: "El repertorio interpretado por la Sociedad de Cuartetos de Madrid (18631894)", Música: Revista del Real Conservatorio Superior de Música de Madrid, n. ${ }^{\circ} 7-9,2000-2002$, pp. 27 142; Fernando Delgado García: "Una tradición olvidada. El cuarteto de cuerda en España (1863-1914)", notas al programa, Fundación Juan March, febrero de 2013.

${ }^{42}$ La Dinastía. Diario político, literario y mercantil, Barcelona, 1-5-1884, p. 18.

${ }^{43}$ Manuela Narváez Ferri: L'Orfeó Català, cant coral i catalanisme (1891-1951), tesis doctoral, Barcelona, Universidad de Barcelona, 2005, pp. 63-65. 
veladas musicales de las antiguas academias dieciochescas, de las sociedades de amigos del país, de los salones aristocráticos y burgueses, de las sociedades musicales y de los cafés.

Un nuevo espacio público que proliferó en muchas ciudades del mundo occidental fueron los jardines de recreo que tuvieron la peculiaridad de que en ellos confluyeron todas las comunidades de públicos de amantes de la música descritos en este artículo. Se trataba de extensos complejos de propiedad privada dentro de las ciudades o en sus suburbios en los que se ofrecía entretenimiento público previo pago de una entrada. Solían tener carácter estacional, abriendo sus puertas a mediados de primavera y cerrándolas a mediados de otoño. El jardín de recreo fue un fenómeno internacional. Los primeros se abrieron en Londres a finales del siglo XVII y se les llamó pleasure gardens. En Inglaterra conocieron su apogeo en la segunda mitad del XVIII cuando los jardines deVauxhall y Ranelagh se convirtieron en modelos exportados a otras partes de Europa. Los parisinos pronto crearon su versión de jardín cuyo modelo fue el parque de Tívoli, hoy desaparecido, que fue ampliamente reproducido en muchas ciudades del continente a lo largo del siglo XIX ${ }^{44}$. Los jardines de recreo reflejaban el espíritu "democratizador" de la burguesía liberal del siglo XIX, pero también los límites restrictivos de dicho espíritu. La admisión general se controlaba de manera indirecta con la oferta de actividades de alto precio, tales como las representaciones operísticas, los conciertos de música clásica o los bailes de sociedad que además requerían una estricta etiqueta en el vestido y el comportamiento con el fin de garantizar exclusividad y orden.

El primer jardín de recreo abierto en España fue el Jardín de Tívoli en Madrid (1820). Fue recibido como una iniciativa de modernidad que inequívocamente llegó ligada a la experiencia del trienio liberal. A partir de ese momento y, sobre todo, desde 1833, Madrid y Barcelona iniciaron una competición por la apertura de jardines de recreo similar a la descrita para el caso de los teatros de ópera. El caso español muestra cómo el jardín de recreo fue todo un paradigma de modernidad en el que la música jugó un papel esencial. Su historia está ligada a la comercialización del ocio, al consumo, a la creación de nuevas identidades políticas, sociales y culturales y, por supuesto, a la configuración de la esfera pública. Como ya se ha mencionado los jardines constituyeron un microcosmos en el que se pueden

${ }^{44}$ Para la historia de los jardines en el mundo anglosajón véase Jonathan Conlin (ed.): The Pleasure Garden: from Vauxhall to Coney Island, Philadelphia, University of Pennsylvania Press, 2013; para Francia véase Gilles-Antoine Langlois: Folies, Tivolis et attractions: Les premiers parcs de loisirs parisiens, París, 1991; para Alemania, Jürgen Weisser: Zwischen Lustgarten und Lunapark: der Volksgarten in Nymphenburg (1890-1916) und die Entwicklung der kommerziellen Belustigungsgarten, Munchen, 1998. Para el caso español véase Jesús Cruz: "Espacios públicos y modernidad urbana: la historia de los jardines de recreo en la España del siglo XIX", Historia Social, 83, 2015, pp. 37-58. 
observar todos los públicos musicales del siglo XIX. Comenzando con el "paseo concierto" (promenade concert) - una atracción clásica copiada de los parques ingleses- que facilitaba la práctica de una urbanidad cívica en las avenidas arboladas del parque ${ }^{45}$. La música se reproducía desde un templete colocado en la avenida principal donde el público podía pasear mientras escuchaba el concierto generalmente a cargo de una banda militar ${ }^{46}$.

En ocasiones, estas interpretaciones tenían un carácter político ligado al ascenso del liberalismo. Un ejemplo, entre muchos aún por investigar, fue la celebración de un concierto de banda para conmemorar el final de la Primera Guerra Carlista en el Jardín de las Delicias de Madrid el 9 septiembre de 1839. El encuentro estaba organizado por la sección de música del Liceo Artístico e incluyó la interpretación de un nuevo Himno a la Paz con letra de Patricio de la Escosura y música de Joaquín Espín ${ }^{47}$. Esto indica que una parte de la música patriótica y revolucionaria, interpretada e, incluso, compuesta en momentos clave del siglo XIX, tuvo como escenario los jardines de recreo en actividades como la descrita o en otras similares. Como fuera el caso de los banquetes patrióticos que siempre incluían orquestas o bandas que interpretaban los clásicos himnos de Riego, de Espartero, el Trágala y composiciones similares. Algunos de los documentados en Madrid ocurrieron en momentos clave del desarrollo de la revolución liberal, en el Jardín de las Delicias entre 1839 y 1840 y, en 1864, el que reunió en los Campos Elíseos a dos millares de progresistas y que abrió el camino al movimiento que condujo a la Revolución Gloriosa ${ }^{48}$.

Además de las bandas de música, las rondallas, los espectáculos de ópera, zarzuela y los conciertos en los teatros y espacios habilitados para esas funciones, los jardines acogieron públicos y formas musicales no existentes antes del siglo XIX. En Barcelona, dos de sus principales jardines fueron los lugares donde se desarrolló el movimiento coralista impulsado por Anselmo Clavé, del que hablaremos más adelante. La historia de los desarrollos musicales de todos los jardines de recreo españoles, desde el temprano de Tívoli hasta el tardío Jardín del Buen Retiro en Madrid (1876-1905), pasando por los barceloneses y los que pudieron existir en otras ciudades, está todavía en su mayor parte por hacer. Lo que mejor conocemos son las

\footnotetext{
45 Véase William Weber: La gran transformación en el gusto musical: la programación de conciertos de Haydn a Brahms, Madrid, Fondo de Cultura Económica, 2011, cap. 7.

${ }^{46}$ La práctica totalidad de los pleasure gardens ingleses ofrecían este tipo de atracción conocida como promenade concerts. Un anuncio en el Diario de Avisos de Madrid de 5 de junio de 1834, informaba que, en días señalados, durante la estación de apertura y siempre en los días de fiesta, una banda militar amenizaría los jardines con música de zarzuela.

47 Aránzazu Pérez Sánchez: El Liceo Artístico y Literario..., p. 241.

48 Sobre los banquetes patrióticos del Jardín de las Delicias ver Javier Pérez Núñez: "La revolución de 1840: la culminación del Madrid progresista", Cuadernos de Historia Contemporánea, 36, 2014, p. 160. Sobre el banquete de mayo de 1864 ver Jesús Cruz: "Espacios públicos y modernidad urbana...", pp. 51 y 52.
} 
actividades de Clavé en los Jardines de la Ninfa primero, luego de Euterpe y en los Campos Elíseos después (Ilustración 3). De su transcendencia da fe el hecho de que la primera interpretación pública en España de la música de Wagner tuviera lugar en los Campos Elíseos de la mano de Anselmo Clavé ${ }^{49}$. En Madrid, Francisco Asenjo Barbieri se haría cargo en 1864 de la dirección musical del Teatro Rossini, en los recién abiertos Campos Elíseos, donde desplegaría una intensa actividad musical que incluyó la composición de piezas para ser estrenadas exprofeso en los jardines ${ }^{50}$. Bajo sus auspicios Emilio Arrieta compuso una Cantata a Rossini y Bonifacio Eslava una Polka de las modistas para ser interpretadas respectivamente por la orquesta y las bandas militares. Piezas que duermen en los archivos esperando una mano que arranque sus notas y que ilustran la transcendencia que tuvieron aquellos espacios, hoy desaparecidos, en la configuración de la esfera pública española del siglo XIX.

\section{Las bandas de música}

Pasemos a hablar de las ya mencionadas bandas de música,que bien pudieron constituir el colectivo más numeroso de amantes de la música en la esfera pública española a finales del siglo XIX. A las bandas militares existentes en siglos anteriores se fueron añadiendo a lo largo del siglo un abundante número de agrupaciones instrumentales de carácter civil que al igual que los conjuntos corales eran expresión de sentimientos colectivo. Las bandas de música son un fenómeno de nuestra historia poco estudiado, baste señalar que el volumen de Carlos Gómez Amat dedicado al siglo XIX de la historia de la música española, no sólo carece de un capítulo dedicado a las bandas de música, sino que apenas las menciona ${ }^{51}$.

En la constitución de las bandas modernas confluyeron tres tradiciones musicales, una procedente de la iglesia, otra de los ejércitos y una última, más difícil de determinar, de las tradiciones del folklore popular. La música eclesiástica se compuso fundamentalmente para ser interpretada dentro de

${ }^{49}$ Eco de Euterpe. Periódico dedicado exclusivamente a los señores concurrentes a los Campos Eliseos, Barcelona, IV, 154, 16-7-1862. Tanto en Madrid como en Barcelona se vendieron partituras con música de Wagner antes de 1862, por lo que es posible que su música se interpretara con anticipación en algunos conciertos privados. La primera interpretación pública de la música de Wagner en Madrid se programó para el mes de febrero de 1863, pero por una indisposición del intérprete no se hizo efectiva hasta 1864. Véase José Ignacio Suárez: "La recepción de la obra de Richard Wagner en Madrid entre 1861 y 1876", Cuadernos de Música Iberoamericana, 10, 2005, p. 73; Paloma Ortiz de Urbina y Sobrino: La Recepción de Richard Wagner en Madrid (1900-1914), Madrid, tesis doctoral, Universidad Complutense de Madrid, 2005, p. 42.

${ }^{50}$ Emilio Casares Rodicio: Francisco Asenjo Barbieri. 1. El hombre y el creador, Madrid, ICCMU, 1994, p. 243.

${ }^{51}$ Otro tanto ocurre con el volumen editado por E. Casares Rodicio y C. Alonso González: La música española en el siglo XIX, en otros aspectos mucho más elaborado y actualizado. 


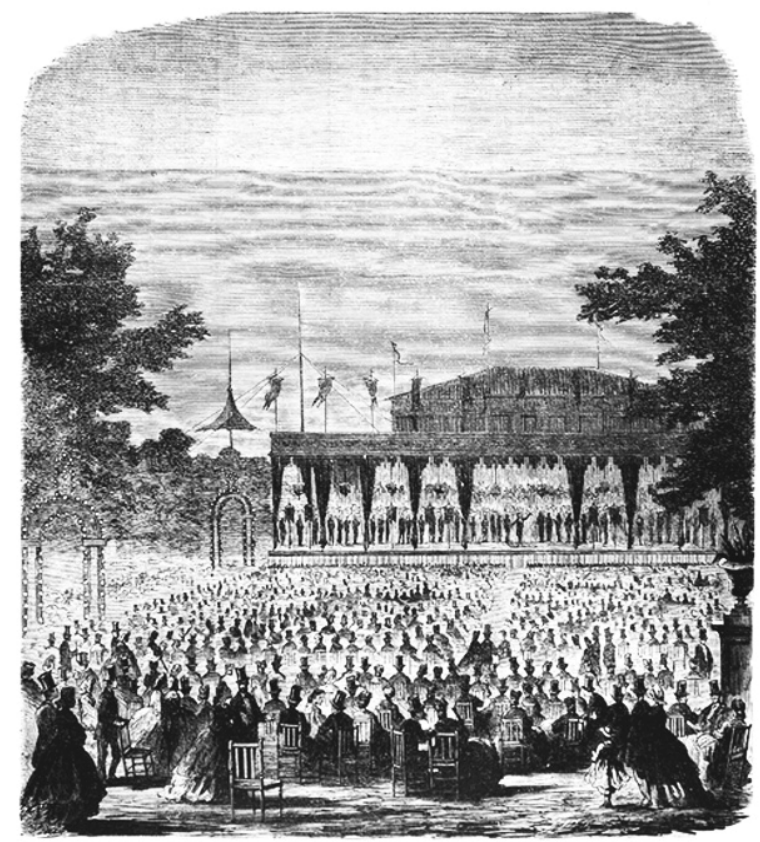

Ilustración 3. Gran concierto de agrupaciones corales organizado por Anselmo Clavé en los Campos Elíseos de Barcelona el 4 y 5 de junio de 1864 (El Museo Universal, 19 de junio de 1864)

las iglesias y otros recintos de carácter sagrado, pero una pequeña porción, a cargo de los ministriles, se sacó a las calles y los campos para acompañar a las procesiones, las romerías y otros actos de carácter religioso. En el norte y centro de Europa las primeras agrupaciones bandísticas de carácter civil, cuya función primordial era tocar música de entretenimiento, fueron las Harmoniemusiken, integradas por sextetos y octetos que proliferaron entre 1760 y $1840^{52}$. No obstante, parece que fue el componente militar el que más influyó en el surgimiento de la banda civil moderna ${ }^{53}$. En todo el mundo occidental las bandas de instrumentos de viento se consolidaron a lo largo del siglo XIX como fenómeno público ligado al ascenso del liberalismo, de la civilidad burguesa y del nacionalismo.

Hay suficiente evidencia como para afirmar que a mediados del XIX ya existían alrededor de un centenar de bandas civiles en diversos lugares de la geografia española y que este número se incrementó notablemente hasta el primer tercio del siglo XX. Cuándo y cómo surgieron las primera bandas

\footnotetext{
52 Frederic Oriola Velló: "Las bandas militares en la España de la Restauración (1874-1931)", Nassarre, 30, 2014, p. 164.

53 Jorge Gil Arráez: "De los instrumentos de guerra a las bandas de música. Una aproximación histórica sobre las primeras bandas de música del ejército español del siglo XVIII”, Música, 21, 2014, p. 35.
} 
civiles en España es una de las primeras cuestiones a poner sobre la mesa para abordar la historia de la banda civil de música española. No parece que en España existiera una tradición de Harmoniemusiken en el siglo XVIII, aunque sí existen testimonios de la existencia de la "rondalla" como una forma musical de raigambre popular que tenía las calles y las plazas como principales escenarios. La evidencia más antigua conocida sobre la existencia de bandas actuando en un acto cívico no militar la encontramos de manera muy difusa en la región levantina.José Rafael PascualVilaplana cita una nota escrita en 1854 por un presbítero erudito local de la villa de Albaida en la que menciona la participación de una banda en las fiestas locales de 1786. El autor la describe como "una música marcial o de retreta, que era de un regimiento que estaba de guarnición en Alicante", y añade que tal circunstancia no volvió a repetirse hasta 1801, aunque esta vez ya con músicos civiles (paisanos) que vinieron de Muro ${ }^{54}$. Un testimonio similar, en este caso escrito en 1910, cita información sobre la intervención de una banda en las fiestas de Aguyent a finales del siglo XVIII ${ }^{55}$. La escueta evidencia presentada permite sugerir que la primeras Harmoniemusiken españolas se dieron a conocer en el valle de Albaida, con músicos que en parte procedían de unidades militares ${ }^{56}$. Esto nos plantea una segunda pregunta: ¿es acertado considerar que los orígenes del movimiento bandístico español se encontrarían en la región Levantina, más concretamente, en las comarcas de La Albaida, El Condado y La Alcoya de la actual Comunidad Valenciana? Y de ser así, ¿cuál sería la razón para explicar este desarrollo histórico?57

De lo que no cabe duda es del origen fundamentalmente militar de las bandas civiles españolas. La evidencia de que disponemos muestra que estas se fueron creando desde mediados de 1840, aunque sus raíces se encuentran en las Milicias Nacionales de voluntarios constituidas en los años veinte y treinta del XIX. La Milicia de voluntarios durante el trienio estaba formada

54 Stephen L. Rhodes y David Hamrick: A History of the Wind Band, Nashville, Lipscomb University, 2007, cap. 4; José Rafael Pascual Vilaplana: "Las bandas de música de la tradición a lo contemporáneo", Eufonía. Didáctica de la Música, 18, 2000, p. 21; el documento titulado Breve historia de la Villa de Albaida (entre 1847 y 1864) Mateu Giner, Francisco, 1793-1865, está digitalizado y se encuentra en La Biblioteca Valenciana Digital (BIVALDI) http://bivaldi.gva.es/es/consulta/resultados_ocr.cmd.

55 Josep Francesc Almería: "De las bandas de música a las sociedades musicales", Las bandas de música de la Comunitat Valenciana: las sociedades musicales, Juan de Dios Leal (ed.), Valencia, Gules, 2014, p. 11.

${ }^{56} \mathrm{Ibid}$., p.141; en la novela Don Lazarillo Vizcardi (escrita entre c. 1798 y c. 1806), Antonio Eximeno hace alusión a la música de un regimiento militar que marcha por la calle de un lugar que cabe identificar con la ciudad de Valencia, mientras una pareja de novios contrae matrimonio en una iglesia. Ver Alberto Hernández Mateos: El pensamiento musical de Antonio de Eximeno..., p. 343.

${ }^{57}$ Los trabajos de Elvira Asensi contienen algunas aproximaciones a estas cuestiones. Elvira Asensi Silvestre: "El certamen de bandas: identidad y confrontación musical en la Valencia del siglo XIX", Nuevos horizontes del pasado. Culturas politicas, identidades y formas de representación: Actas del X Congreso de la Asociación de Historia Contemporánea, 2011, p. 8; id.: Música i societat: esl fenomen de les bandes de música valencianes en la cultura del segle XIX i principi del XX, tesis doctoral, Universitat de València, 2010. 
por varios batallones, cada uno de los cuales, por reglamento, tenía una banda integrada por 15 tambores y 8 pífanos y cornetas ${ }^{58}$. El caso de Alcoy, estudiado por Jaume J. Ferrando, demuestra que la banda civil surgió como una continuidad de la existente de la Milicia Nacional al entrar en vigor el decreto de su disolución en diciembre de 1843. Los integrantes de la banda de la Milicia, un interesante conglomerado social que cubría un espectro diverso desde jornaleros a fabricantes con predominio de la menestralía, pasaron a constituir la primera banda de música civil de la ciudad en $1844^{59}$. Este modelo se repite en muchos otros casos entre los estudiados a nivel local. En Requena, por ejemplo, la conocida como "Charanga o Música Municipal" de mediados del siglo XIX se constituyó como una agrupación surgida en 1832 de la "Música de la Milicia”, después llamada "Charanga de los estudiantes" y "Charanga de los milicianos". La de Albacete, una de las bandas municipales más antiguas de España, se constituyó el 16 de marzo de 1859, al expedir el Ayuntamiento título de contrato a favor de Salvador Saldaña para el cargo de "Maestro director", aunque su presencia se remonta al año 1840, cuando se denominaba "Banda del Batallón de la Milicia Nacional". En Calahorra la visita del general Espartero en 1856 fue recibida por la banda de la milicia compuesta por 21 músicos que actuaron en distintos festejos con un salario de cuatro reales a cada uno. Ese mismo año se disolvió la milicia y se creó la banda con los instrumentos que pertenecían al municipio. La primera referencia documental a la Banda de Música de Pegalajar (Jaén) data de 1854, cuando tras la revolución liberal progresista de ese año y para manifestar la alegría popular, la banda tocó el Himno de Riego en la Plaza ante la multitud, entre repique general de campanas, disparos de armas de fuego y vivas al General.

Sisinio Pérez Garzón ha señalado cómo en los presupuestos de creación y mantenimiento de la milicia la banda tenía prioridad sobre, por ejemplo, el armamento, porque la banda cumplía además funciones propagandísti$\operatorname{cas}^{60}$. Este es un aspecto fundamental para entender la historia de las comunidades de amantes de la música y el público musical que integraron este movimiento. Las bandas fueron un elemento fundamental para la construcción de los rituales, festividades simbólicas y actos conmemorativos ligados a la construcción del estado liberal. La inauguración y las celebraciones ligadas a la multiplicidad de lugares de memoria construidos a lo largo del siglo XIX siempre contaban con una banda para ensalzar el acto

\footnotetext{
58 Juan Sisinio Pérez Garzón: Milicia nacional y revolución burguesa: el prototipo madrileño, 1808-1874, Madrid, CSIC, Instituto Jerónimo Zurita, 1978, p. 174.

59 Jaume J. Ferrando: "Els músics que contribuïren a fer d'Alcoi una ciutat. Apunts sobre la Banda de Música de la Milicia Nacional", Periódico Ciudad de Alcoy, 20-11-2010.

60 Pérez Garzón: Milicia nacional y revolución burguesa..., p. 134.
} 
con la interpretación de himnos o piezas musicales de contenido y tradición revolucionaria. Las bandas animaban las conmemoraciones de las efemérides de los héroes liberales, desde los de la Guerra de la Independencia a las populares fiestas de San Baldomero de los años previos a La Gloriosa. Las procesiones cívicas en defensa de los valores constitucionales, como las organizadas en Madrid para celebrar la constitución de 1837 o las que tuvieron lugar entre el 2 y el 6 de mayo de 1864, no se pueden concebir sin la presencia de diversas bandas de música como parte esencial de su aparato propagandístico. Por otra parte, algunos de los prohombres de la música en la España de mediados del XIX tuvieron su primera formación en una banda civil de música. Ruperto Chapí mostró su talento desde los ocho años como componente de la banda municipal deVillena. Barbieri en 1843 se ganaba la vida como primer clarinete en la Banda del Quinto Batallón de la Milicia Nacional de Madrid, clarinete murguista en teatros caseros y bailes particulares, pianista en tertulias. Durante aquellos años se hinchó a tocar el Himno de Riego, el de Los milicianos somos nacionales y el de Espartero.

Las bandas constituyeron el principal engranaje entre el público musical selecto y el público musical popular. Las integraban aficionados en su mayor parte procedentes de la menestralía y de las clases trabajadoras con voluntad de adquirir cultura y ser cívicamente y, en muchos casos políticamente, activos. Popularizaron la música a través de los conciertos públicos en los quioscos de música de las plazas, parques y jardines de recreo con conciertos que incluían himnos y piezas de compositores europeos y españoles. Como ya hemos visto en el caso de otras comunidades de público musical en España, su historia está escrita a retazos. Por ello, urge una historia integral que contemple la génesis de las bandas civiles españolas como parte de un fenómeno europeo ligado a la configuración las esferas públicas nacionales, a la creación de nuevas identidades en una época de cambio político y social y, en definitiva, a la modernidad ${ }^{61}$.

\section{Las agrupaciones corales}

La última comunidad pública de amantes de la música a contemplar en este artículo es la que constituyeron las agrupaciones corales ${ }^{62}$. Los coros, como las bandas, fueron nexo de unión entre públicos musicales, aunque como fenómeno de sociabilidad estos tuvieron una difusión menos amplia

${ }^{61}$ Pueden servir como modelo los siguientes trabajos: Richard K. Hansen: The American Wind Band: A Cultural History, Chicago, GIA Publications, 2005; Armand Raucoules: De la musique et des militaires, París, Ministère de la défense, 2008; Elmar Walter: Blas- und Bläsermusik: Musik zwischen Volksmusik, volkstümlicher Musik, Militärmusik und Kunstmusik, Tutzing, Hans Schneider, 2011.

62 El fenómeno coral surgió en Cataluña y el País Vasco, por ello, son los casos más estudiados. Véase J. Carbonell i Guberna: "Aportaciones al estudio de la sociabilidad coral en la España contemporánea", 
que aquellas. No cabe duda de que el coralismo como movimiento asociativo surgió en Cataluña promovido e inspirado por Anselmo Clavé en 1857 con la Sociedad Musical Euterpe.Tampoco se puede cuestionar que fueron más fuertes en las zonas industrializadas y que arraigaron con más vigor en regiones que han desarrollado fuertes movimientos nacionalistas en el siglo XX. Como ha señalado Jaume Carbonell i Guberna el coro/orfeón es una expresión de sentimiento colectivo, de esfuerzo colectivo y de identidad colectiva, como también lo fueron las bandas de música ${ }^{63}$. Es cierto que los coros pueden tener una impronta más nostálgica, más evocadora de las identidades locales y nacionales, por eso se vienen estudiando como manifestaciones de nacionalismo, en el sentido de la invención de la tradición. No es extraño así que, en España, ciertas interpretaciones recientes del fenómeno hayan enfatizado este aspecto argumentando la existencia de "diferentes realidades nacionales en el siglo XIX" ${ }_{64}$. El problema es que esta manera de ver las cosas puede pecar de anacronismo, de hacer una interpretación más mediatizada por desarrollos políticos posteriores que por las intenciones originales de quienes iniciaron este movimiento.

Lo que significaba el coralismo para sus promotores en el XIX lo reflejó mejor que nadie Mariano Soriano Fuertes en su memoria de 1865 sobre las asociaciones corales impulsadas por Clavé. Según Soriano, la iniciativa de Clavé buscaba la creación de un movimiento cívico para proporcionar educación y promover formas de sociabilidad civilizada entre las clases trabajadoras. Un movimiento al estilo de los existentes en otros países de Europa, más concretamente en Suiza, Alemania, Inglaterra, Bélgica y Francia ${ }^{65}$. Soriano, sin negar la vocación liberal progresista de Anselmo Clavé, no contempló que su intención fuera modelar una identidad nacional catalana ni conducir al proletariado hacia un proceso revolucionario. Soriano era gran admirador, amigo y colaborador de Clavé y ambos compartían ideas y visiones que se podrían resumir en la voluntad de modernizar la sociedad española para colocarla al nivel de las más adelantadas del contexto europeo. Soriano admiraba y respetaba el trabajo desarrollado por Clavé para rescatar tradiciones folclóricas catalanas y para componer nuevas músicas inspiradas en aquellas. Clavé, por su parte, en el momento más brillante de su carrera, cuando organizó en los Campos Elíseos de Barcelona su Se-

\footnotetext{
Hispania, 214, 2003, p. 486; María Nagore Ferrer: "Un aspecto del asociacionismo musical en España: las sociedades corales", Cuadernos de Música Iberoamericana, Madrid, 8, 2001, pp. 211-226; id.: "Orígenes del movimiento coral en Bilbao en el siglo XIX", Revista de Musicología, 14, 1991, pp. 125-134; id.: La revolucion coral. Estudio sobre la Sociedad Coral de Bilbao y el movimiento coral europeo (1800-1936), Madrid, ICCMU, 2001.

${ }^{63} \mathrm{~J}$. Carbonell i Guberna: "Aportaciones al estudio de la sociabilidad coral...", p. 486.

${ }^{64}$ Ibid., p. 502.

${ }_{65}$ Mariano Soriano Fuertes: Memoria sobre las Sociedades Corales en España, p. 13.
} 
gundo Concurso Coral, incluyó en el programa la cantata ¡España!, para ser interpretada por un coro de 2.300 voces. El maestro compuso esta pieza exprofeso para la ocasión y su primera estrofa rezaba:"Gloria a España, la heroica matrona / que humilló la extranjera arrogancia, / invencible en Sagunto y Numancia, / Covadonga, Gerona y el Bruch"66.

Parece muy probable que el asociacionismo coral tuviera un asentamiento más sólido en Cataluña y el País Vasco, que fuera más débil en Castilla y, al menos en sus inicios, no estuviera conectado entre sí. No obstante recientes investigaciones muestran que en el último tercio del siglo XIX existieron iniciativas de asociacionismo coral en lugares que nos eran des$\operatorname{conocidos}^{67}$. Una vez más el avance de la investigación se hace imprescindible para un mejor conocimiento de la aportación del coralismo a la configuración del público musical y de la esfera pública en la España del siglo XIX.

\section{Conclusión}

De todo lo expuesto, se deduce con claridad que, en los albores del siglo $\mathrm{XX}$, aquel incipiente y todavía mal conocido público musical de finales del XVIII se había transformado en un complejo y diverso conglomerado de comunidades musicales parte integral de la esfera pública española. En España, como en el resto de Europa, la música contribuyó a la configuración de la esfera pública a través de la proliferación de la figura del amante de la música. Aunque la secuencia de creación de comunidades de amantes de la música en España llevara cierto retraso respecto al norte y centro de Europa, los resultados a medio plazo no fueron tan diferentes.

Tampoco ese proceso fue lineal dentro de los territorios que integraron el nuevo estado liberal español. Las áreas de mayor dinamismo económico y las más urbanizadas como Cataluña, País Vasco,Valencia y Madrid fueron pioneras en la creación de comunidades de oyentes, opinantes e intérpretes musicales. Como en otros aspectos de la incorporación a la modernidad, Barcelona y Madrid fueron sempiternas competidoras en una carrera en la que la capital de Cataluña solió ser una alumna más aplicada. La aportación a la esfera pública de cada una de las diversas comunidades musicales tuvo rasgos comunes que eran expresión de una formativa identidad musical española, pero a diferencia de lo que ocurriera en otros países como

${ }^{66}$ Eco de Euterpe. Periódico dedicado exclusivamente a los señores concurrentes a los Campos Eliseos, Barcelona, 238, 4-6-1864.

${ }^{67}$ Joaquina Labajo Valdés: Aproximación al fenómeno orfeonístico en España: Valladolid 1890-1923, Diputación Provincial de Valladolid, 1987; Enrique Encabo Fernández: "Actividad orfeonística en Murcia (1867-1933): de la Sociedad Filarmónica al Orfeón Murciano Fernández Caballero”, Nassarre, 28, 2012, pp. 143-172. 
Francia, Alemania o Italia, esa identidad estuvo mucho más mediatizada por los desequilibrios regionales y por el peso de las identidades locales.

En su gestación, las comunidades de público musical estuvieron integradas por grupos sociales o profesionales muy restringidos: miembros de la nobleza, familias musicales o burgueses acomodados. Con el paso del tiempo ese espectro social se fue abriendo a las clases medias con la proliferación de la música de tertulia, la música de teatro, la ópera, los cafés y el concierto público. A principios del siglo XX la base social del público musical se había extendido a segmentos amplios de la menestralía y de las clases trabajadoras a través de las asociaciones de bandas de música, de los ateneos y casinos populares, de las agrupaciones corales e incluso de las organizaciones de clase.

Como se ha reiterado a lo largo del artículo es mucho lo que queda por investigar sobre el proceso configurativo de las comunidades que integraron el público musical español en la época liberal y sobre la manera en que contribuyeron a configurar la esfera pública española. En las páginas precedentes se han identificado seis principales comunidades de amantes de la música, algunas originadas en el último tercio del siglo XVIII, otras surgidas a tenor de los cambios sociales y políticos que caracterizaron aquel periodo histórico. Como señalé al principio, mi intención no era ofrecer resultados concluyentes, sino, por el contrario, plantear problemas, hacer sugerencias y marcar pautas con el fin de estimular el debate y la investigación. Espero haber cumplido ese objetivo. 